\title{
Pyridine- and Imidazoledicarboxylates of Zinc: Hydrothermal Synthesis, Structure, and Properties
}

\author{
Partha Mahata $^{[a]}$ and Srinivasan Natarajan*[a]
}

Keywords: Luminescence / N ligands / Pi interactions / Zinc

The reaction of hetrocyclic dicarboxylic acids, such as pyridine-2,5-dicarboxylic acid and imidazole-4,5-dicarboxylic acid, under hydrothermal conditions in the presence of an appropriate zinc salt yields three new zinc coordination polymers ${ }_{\infty}^{0}\left[\left\{\mathrm{Zn}_{2}\left(\mathrm{H}_{2} \mathrm{O}\right)_{4}\right\}\left\{\mathrm{C}_{5} \mathrm{H}_{3} \mathrm{~N}(\mathrm{COO})_{2}\right\}_{2}\right] \quad(\mathbf{1}), \quad{ }_{\infty}^{1}\left[\left\{\mathrm{Zn}\left(\mathrm{C}_{12} \mathrm{H}_{8} \mathrm{~N}_{2}\right)\right\}-\right.$ $\left.\left\{\mathrm{C}_{5} \mathrm{H}_{3} \mathrm{~N}(\mathrm{COO})_{2}\right\} \cdot 0.5 \mathrm{H}_{2} \mathrm{O}\right](2)$, and $1_{\infty}^{1}\left[\left\{\mathrm{Zn}\left(\mathrm{C}_{12} \mathrm{H}_{8} \mathrm{~N}_{2}\right)\right\}\left\{\mathrm{C}_{3} \mathrm{HN}_{2}-\right.\right.$ $\left.(\mathrm{COO})_{2}\right\}$ ] (3). While 1 forms with a zero-dimensional molecular rectangular box structure, $\mathbf{2}$ and $\mathbf{3}$ have zig-zag one-dimensional chain structures. The $\mathrm{Zn}^{2+}$ ions are coordinated by both the carboxylate oxygen atoms and also by the nitrogen atoms of the heterocycles. The 1,10-phenanthroline molecules in $\mathbf{2}$ and $\mathbf{3}$ act as a secondary ligands and occupy the inter-chain spaces. The moderate hydrogen-bond interaction energy in $\mathbf{1}$ and the $\pi \cdots \pi$ interactions in $\mathbf{2}$ and $\mathbf{3}$ appear to play an important role for the structural stability. The structures of $\mathbf{2}$ and $\mathbf{3}$ appear to be related, even though they are formed with different carboxylic acids. All three compounds exhibit photoluminescence at room temperature.

\section{Introduction}

Research in the area of metal-organic frameworks (MOFs) exhibiting open structures continues to be interesting due to their many applications, both actual as well as potential. ${ }^{[1]}$ Of the many MOF compounds investigated, those containing benzenecarboxylates constitute an important family ${ }^{[1-10]}$ as they combine the principles of supramolecular chemistry along with favorable $\pi \cdots \pi$ interactions that give rise to fascinating crystal structures. The role of hydrogen bonding in metal-coordinated network structures is beginning to gain importance as it results in a large number of coordination polymers. Recently, the scope of the investigations on benzenecarboxylates has been enhanced by the use of heterocyclic carboxylic acids such as pyridine-, pyrazole-, and imidazolecarboxylic acids. These acids can act both as a multiple proton donor and acceptor and can use their carboxylate oxygen and nitrogen atoms, which are highly accessible to metal ions, to form interesting network structures. Thus, Lin and co-workers have employed pyridinecarboxylic acid to prepare a series of $\mathrm{Zn}^{2+}$ and $\mathrm{Cd}^{2+}$ coordination polymers using a molecular building-block approach. ${ }^{[1-14]}$ Pyrazoledicarboxylates have also given rise to interesting network structures of varying dimensionality. ${ }^{[15-17]}$ Although many polymeric complexes have been prepared employing heterocyclic carboxylates, previously uncharacterized compounds with novel crystal

[a] Framework Solids Laboratory, Solid State and Structural Chemistry Laboratory, Indian Institute of Science Bangalore 560012, India

E-mail: snatarajan@sscu.iisc.ernet.in

Supporting information for this article is available on the WWW under http://www.eurjic.org or from the author. structures often emerge during hydrothermal synthetic conditions. We have combined the advantages of the hydrothermal method of synthesis and multifunctional carboxylic acids in the presence of 1,10-phenanthroline to form a large number of new inorganic coordination polymers. ${ }^{[18,19]}$ In continuation of this theme, we have now synthesized three new $\mathrm{Zn}$ coordination polymers, namely ${ }_{\infty}^{0}\left[\left\{\mathrm{Zn}_{2}\left(\mathrm{H}_{2} \mathrm{O}\right)_{4}\right\}-\right.$ $\left.\left\{\mathrm{C}_{5} \mathrm{H}_{3} \mathrm{~N}(\mathrm{COO})_{2}\right\}_{2}\right](\mathbf{1}),{ }_{\infty}^{1}\left[\left\{\mathrm{Zn}\left(\mathrm{C}_{12} \mathrm{H}_{8} \mathrm{~N}_{2}\right)\right\}\left\{\mathrm{C}_{5} \mathrm{H}_{3} \mathrm{~N}(\mathrm{COO})_{2}\right\} \cdot\right.$ $\left.0.5 \mathrm{H}_{2} \mathrm{O}\right]$ (2), and ${ }_{\infty}^{1}\left[\left\{\mathrm{Zn}\left(\mathrm{C}_{12} \mathrm{H}_{8} \mathrm{~N}_{2}\right)\right\}\left\{\mathrm{C}_{3} \mathrm{HN}_{2}(\mathrm{COO})_{2}\right\}\right]$ (3), by employing pyridine- and imidazoledicarboxylic acids. Compounds 1 and $\mathbf{2}$ were prepared from pyridine-2,5-dicarboxylic acid, whereas 3 was prepared from imidazole4,5-dicarboxylic acid. While 1 possesses a zero-dimensional structure with a rectangular molecular-box arrangement, 2 and $\mathbf{3}$ have one-dimensional structures and all the structures are stabilized by hydrogen-bonding and $\pi \cdots \pi$ interactions. In this paper we describe the synthesis, structure, and properties of these compounds.

\section{Results and Discussion}

The asymmetric unit of $\mathbf{1}$ consists of 30 non-hydrogen atoms, of which two zinc atoms are crystallographically independent (Figure 1). Both the $\mathrm{Zn}^{2+}$ ions have a distorted square-pyramidal geometry formed by two carboxylate oxygen atoms, two bonded water molecules and a nitrogen atom of the pyridine ring. An average distance of 2.0395 and $2.092 \AA$ for the $\mathrm{Zn}-\mathrm{O}$ and $\mathrm{Zn}-\mathrm{N}$ bonds, respectively, results from this connectivity. The $\mathrm{O} / \mathrm{N}-\mathrm{Zn}-\mathrm{O} / \mathrm{N}$ bond angles are in the range 78.01(2)-156.2(2) ${ }^{\circ}$. There are two different pyridine-2,5-dicarboxylate anions present in the structure and all the carboxylate groups have only mono- 
dentate connectivity with the $\mathrm{Zn}^{2+}$ cations. The bond lengths and angles associated with the pyridine-2,5-dicarboxylate anions are in the range expected for this type of bonding. The terminal $\mathrm{Zn}-\mathrm{O}$ bonds formed by the oxygen atoms $[\mathrm{O}(1)$ and $\mathrm{O}(4)$ for $\mathrm{Zn}(1)$ and $\mathrm{O}(6)$ and $\mathrm{O}(8)$ for $\mathrm{Zn}(2)]$ are formally water molecules. The two proton positions observed in the difference Fourier map for each of these oxygen atoms also confirm this. Selected bond lengths and angles are listed in Table 1 . The connectivity between $\mathrm{Zn}^{2+}$ and the pyridine-2,5-dicarboxylate anions gives rise to a zero-dimensional unique molecular box. Each molecular box consists of four $\mathrm{Zn}^{2+}$ cations and four carboxylate anions, as shown in Figure 2a. The terminal water molecules and the presence of terminal $\mathrm{C}-\mathrm{O}$ bonds in $\mathbf{1}$ gives rise to a large number of significant $\mathrm{O}-\mathrm{H} \cdots \mathrm{O}$ hydrogen bonds. The hydrogen-bond interactions between the molecular box units form an extended two-dimensional structure (Figure $2 \mathrm{~b}$ and $\mathrm{c}$ ). Both intra- and intermolecular box hydrogen bonds are observed in 1; a complete list of these interactions is given in Table 2.

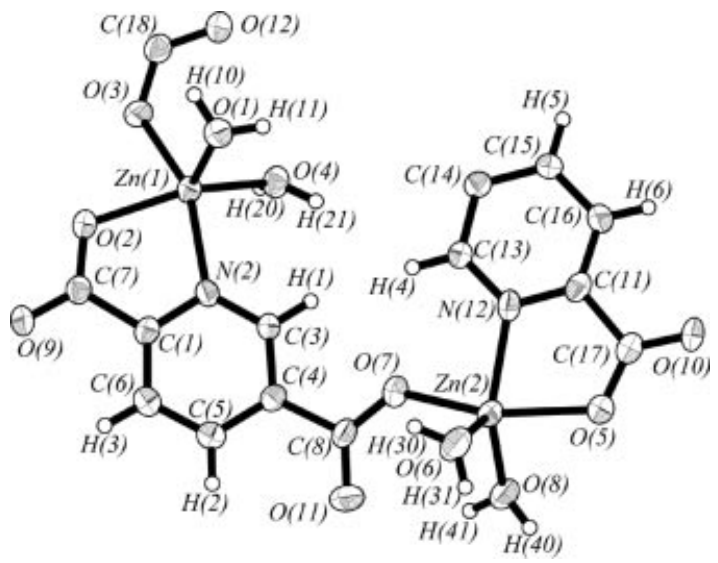

Figure 1. ORTEP drawing of ${ }_{\circ}^{0}\left[\left\{\mathrm{Zn}_{2}\left(\mathrm{H}_{2} \mathrm{O}\right)_{4}\right\}\left\{\mathrm{C}_{5} \mathrm{H}_{3} \mathrm{~N}(\mathrm{COO})_{2}\right\}_{2}\right]$ (1) showing the asymmetric unit. Thermal ellipsoids are given at $50 \%$ probability.

Table 1. Selected bond lengths $[\AA]$ and angles $\left[^{\circ}\right]$ in ${ }_{\infty}^{0}\left[\left\{\mathrm{Zn}_{2}-\right.\right.$ $\left.\left.\left(\mathrm{H}_{2} \mathrm{O}\right)_{4}\right\}\left\{\mathrm{C}_{5} \mathrm{H}_{3} \mathrm{~N}(\mathrm{COO})_{2}\right\}_{2}\right](\mathbf{1})$.

\begin{tabular}{lclc}
\hline $\mathrm{Zn}(1)-\mathrm{O}(1)$ & $2.012(5)$ & $\mathrm{Zn}(2)-\mathrm{O}(5)$ & $2.103(5)$ \\
$\mathrm{Zn}(1)-\mathrm{O}(2)$ & $2.113(4)$ & $\mathrm{Zn}(2)-\mathrm{O}(6)$ & $1.983(6)$ \\
$\mathrm{Zn}(1)-\mathrm{O}(3)$ & $2.022(5)$ & $\mathrm{Zn}(2)-\mathrm{O}(7)$ & $2.036(5)$ \\
$\mathrm{Zn}(1)-\mathrm{O}(4)$ & $2.039(5)$ & $\mathrm{Zn}(2)-\mathrm{O}(8)$ & $2.008(5)$ \\
$\mathrm{Zn}(1)-\mathrm{N}(2)$ & $2.113(5)$ & $\mathrm{Zn}(2)-\mathrm{N}(12)$ & $2.070(6)$ \\
$\mathrm{O}(1)-\mathrm{Zn}(1)-\mathrm{O}(3)$ & $100.1(2)$ & $\mathrm{O}(6)-\mathrm{Zn}(2)-\mathrm{O}(8)$ & $113.4(2)$ \\
$\mathrm{O}(1)-\mathrm{Zn}(1)-\mathrm{O}(4)$ & $102.5(2)$ & $\mathrm{O}(6)-\mathrm{Zn}(2)-\mathrm{O}(7)$ & $99.6(2)$ \\
$\mathrm{O}(3)-\mathrm{Zn}(1)-\mathrm{O}(4)$ & $91.1(2)$ & $\mathrm{O}(8)-\mathrm{Zn}(2)-\mathrm{O}(7)$ & $89.6(2)$ \\
$\mathrm{O}(1)-\mathrm{Zn}(1)-\mathrm{O}(2)$ & $105.7(2)$ & $\mathrm{O}(6)-\mathrm{Zn}(2)-\mathrm{N}(12)$ & $111.0(2)$ \\
$\mathrm{O}(3)-\mathrm{Zn}(1)-\mathrm{O}(2)$ & $83.05(2)$ & $\mathrm{O}(8)-\mathrm{Zn}(2)-\mathrm{N}(12)$ & $135.5(2)$ \\
$\mathrm{O}(4)-\mathrm{Zn}(1)-\mathrm{O}(2)$ & $151.7(2)$ & $\mathrm{O}(7)-\mathrm{Zn}(2)-\mathrm{N}(12)$ & $86.8(2)$ \\
$\mathrm{O}(1)-\mathrm{Zn}(1)-\mathrm{N}(2)$ & $99.7(2)$ & $\mathrm{O}(6)-\mathrm{Zn}(2)-\mathrm{O}(5)$ & $102.8(2)$ \\
$\mathrm{O}(3)-\mathrm{Zn}(1)-\mathrm{N}(2)$ & $155.9(2)$ & $\mathrm{O}(8)-\mathrm{Zn}(2)-\mathrm{O}(5)$ & $88.6(2)$ \\
$\mathrm{O}(4)-\mathrm{Zn}(1)-\mathrm{N}(2)$ & $98.0(2)$ & $\mathrm{O}(7)-\mathrm{Zn}(2)-\mathrm{O}(5)$ & $156.2(2)$ \\
$\mathrm{O}(2)-\mathrm{Zn}(1)-\mathrm{N}(2)$ & $78.44(2)$ & $\mathrm{N}(12)-\mathrm{Zn}(2)-\mathrm{O}(5)$ & $78.01(2)$ \\
\hline
\end{tabular}

The asymmetric unit of 2 consists of 28 non-hydrogen atoms, of which only one $\mathrm{Zn}$ atom is crystallographically independent (Figure 3). The $\mathrm{Zn}^{2+}$ ions have a distorted octahedral geometry formed by three carboxylate oxygen atoms and three nitrogen atoms, two of which belong to the 1,10-phenanthroline ligand. The $\mathrm{Zn}-\mathrm{O}$ and the $\mathrm{Zn}-\mathrm{N}$ bonds have average values of 2.162 and $2.145 \AA$, respectively. The $\mathrm{O} / \mathrm{N}-\mathrm{Zn}-\mathrm{O} / \mathrm{N}$ bond angles are in the range $58.98(2)-164.70(2)^{\circ}$, thereby indicating the heavy distortion of the $\mathrm{Zn}^{2+}$ octahedra (ideal octahedral values are $90^{\circ}$ and $180^{\circ}$ ). The two carboxylate units of the pyridine-2,5-dicarboxylate show differences in their connectivity with respect to the $\mathrm{Zn}^{2+}$ ions - one has a monodentate connectivity and the other a bis(didentate) connectivity. The bond lengths and angles associated with the carboxylate group have typical values. Selected bond lengths and angles are listed in Table 3. In 2, the connectivity between $\mathrm{Zn}^{2+}$ and the pyridine-2,5-carboxylate units gives rise to one-dimensional zigzag chains (Figure 4). The 1,10-phenanthroline molecules act as a ligand to the $\mathrm{Zn}^{2+}$ ions and occupy the inter-chain spaces, along with the lattice water, and contribute to the stability of $\mathbf{2}$ by forming favorable $\pi \cdots \pi$ interactions (Figure 4). The presence of these interactions gives rise to a channel-like structure in $\mathbf{2}$. Unlike $\mathbf{1}$, no significant hydrogen-bond interactions are observed in $\mathbf{2}$.

The asymmetric unit of $\mathbf{3}$ consists of 26 non-hydrogen atoms, of which only one $\mathrm{Zn}$ atom is crystallographically independent (Figure 5). The $\mathrm{Zn}^{2+}$ ions have a distorted octahedral geometry formed by two carboxylate oxygen atoms and four nitrogen atoms, two of which belong to the 1,10phenanthroline ligand and the other two to the imidazole ring. The $\mathrm{Zn}-\mathrm{O}$ and $\mathrm{Zn}-\mathrm{N}$ bonds have average values of $2.225 \AA$ and $2.151 \AA$, respectively. The $\mathrm{O} / \mathrm{N}-\mathrm{Zn}-\mathrm{O} / \mathrm{N}$ bond angles are in the range $74.63(8)-171.54(8)^{\circ}$, thereby indicating distortion of the $\mathrm{Zn}^{2+}$ octahedra. Both the carboxylate groups of the imidazole-4,5-dicarboxylate have only monodentate connectivity with $\mathrm{Zn}^{2+}$ ions. The bond lengths and angles associated with the imidazole-4,5-dicarboxylate have typical values. Selected bond lengths and angles are given in Table 3. The connectivity between the $\mathrm{Zn}^{2+}$ and the imidazole-4,5-carboxylate units gives rise to one-dimensional zig-zag chains (Figure 6). The 1,10-phenanthroline molecules act as a ligand to the $\mathrm{Zn}^{2+}$ ions and occupy the interchain spaces (Figure 6).

Room-temperature solid-state photoluminescence studies performed on powdered samples are presented in Figure 7. Photoluminescence studies of coordination polymers of the type discussed here have been investigated in great detail during the past few years. ${ }^{[19-28]}$ In our present study, we found that coordination polymers 1-3 all exhibit photoluminescence. Compound $\mathbf{1}$ exhibits a single broad emission band at $430 \mathrm{~nm}$, whilst compounds 2 and $\mathbf{3}$ exhibit two peaks at about $375 \mathrm{~nm}$ and at $390 \mathrm{~nm}$ when excited at $337 \mathrm{~nm}$. The emission peak at $430 \mathrm{~nm}$ for 1 and at about $375 \mathrm{~nm}$ for $\mathbf{2}$ and $\mathbf{3}$ can be assigned to the intraligand fluorescent emission, since the acid displays a rather weak emission $\left(\lambda_{\max }=410 \mathrm{~nm}\right)$. The lifetime, $\tau$, for the emissions are 0.016 and $0.018 \mathrm{~ns}$ for $\mathbf{2}$ and 3, respectively. This indicates that the luminescence should be assigned to fluorescence. The peak at $390 \mathrm{~nm}$ observed for $\mathbf{2}$ and $\mathbf{3}$ can be assigned to intraligand emission from the 1,10-phenanthroline ligand. ${ }^{[28]}$ Similar ligand-to-metal charge transfer (LMCT) 


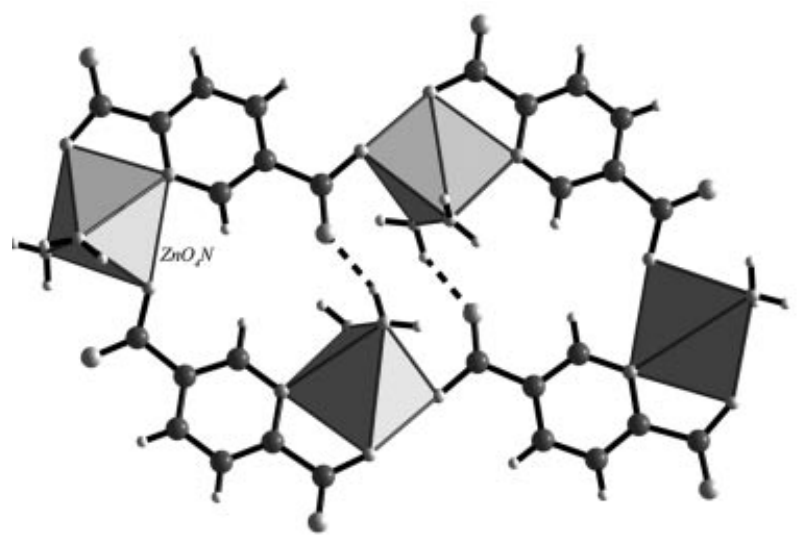

(a)

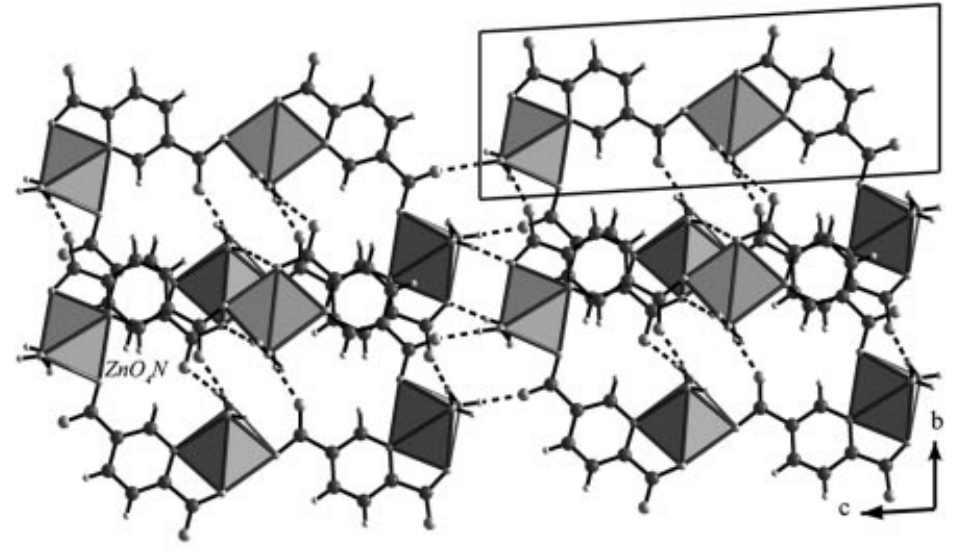

(b)

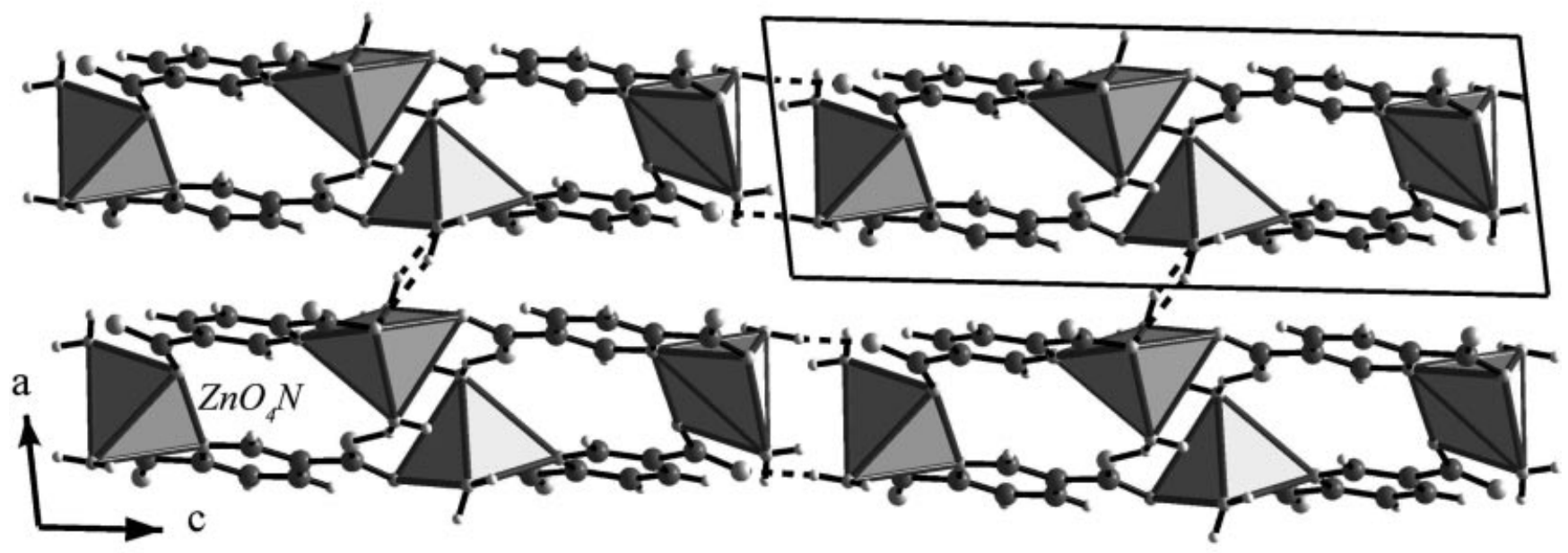

(c)

Figure 2. (a) A figure showing the connectivity between the $\mathrm{Zn}^{2+}$ ions and the pyridine-2,5-dicarboxylate anions. Note that the connectivity forms a molecular box. Dotted lines represent hydrogen-bond interactions. (b) The connectivity between the molecular box in the $b c$ plane. Dotted lines represent hydrogen-bond interactions. (c) The connectivity between the molecular box in the $a c$ plane.

Table 2. Selected hydrogen-bond interactions in ${ }_{\infty}^{0}\left[\left\{\mathrm{Zn}_{2}\left(\mathrm{H}_{2} \mathrm{O}\right)_{4}\right\}-\right.$ $\left.\left\{\mathrm{C}_{5} \mathrm{H}_{3} \mathrm{~N}(\mathrm{COO})_{2}\right\}_{2}\right](\mathbf{1})$.

\begin{tabular}{lcccc}
\hline $\mathrm{D}-\mathrm{H} \cdots \mathrm{A}^{[\mathrm{a}]}$ & $\begin{array}{c}\mathrm{D}-\mathrm{H} \\
{[\AA]}\end{array}$ & $\begin{array}{c}\mathrm{H} \cdots \mathrm{A} \\
{[\AA]}\end{array}$ & $\begin{array}{c}\mathrm{D} \cdots \mathrm{A} \\
{[\AA]}\end{array}$ & $\begin{array}{c}\mathrm{D}-\mathrm{H} \cdot \cdots \mathrm{A} \\
{\left[{ }^{\circ}\right]}\end{array}$ \\
\hline $\mathrm{O}(1)-\mathrm{H}(10) \cdots \mathrm{O}(2)^{\# 1}$ & 0.85 & 2.09 & $2.882(8)$ & 156 \\
$\mathrm{O}(1)-\mathrm{H}(11) \cdots \mathrm{O}(12)^{\# 2}$ & 0.85 & 1.87 & $2.676(7)$ & 156 \\
(intra) & & & & \\
$\mathrm{O}(4)-\mathrm{H}(20) \cdots \mathrm{O}(2)^{(\# 3}$ & 0.85 & 2.13 & $2.943(8)$ & 159 \\
$\mathrm{O}(4)-\mathrm{H}(21) \cdots \mathrm{O}(9)^{\# 4}$ & 0.85 & 1.79 & $2.618(8)$ & 166 \\
$\mathrm{O}(6)-\mathrm{H}(30) \cdots \mathrm{O}(10)^{\# 1}$ & 0.85 & 1.89 & $2.726(9)$ & 173 \\
$\mathrm{O}(6)-\mathrm{H}(31) \cdots \mathrm{O}(11)^{\# 5}$ & 0.85 & 1.81 & $2.653(8)$ & 171 \\
$\mathrm{O}(8)-\mathrm{H}(40) \cdots \mathrm{O}(5)^{\# 6}$ & 0.85 & 1.85 & $2.674(8)$ & 162 \\
$\mathrm{O}(8)-\mathrm{H}(41) \cdots \mathrm{O}(10)^{\# 3}$ & 0.85 & 2.45 & $3.202(9)$ & 147 \\
\hline
\end{tabular}

[a] \#1: $1-x,-y, 1-z ; \# 2: 2-x, 1-y, 1-z ; \# 3: 1-x, 1-y, 1-$ $z ; \# 4: x,-1+y, z ; \# 5: 1-x,-y,-z ; \# 6: x,-1+y,-1+z$. transitions have been observed in many metal-organic coordination polymers. ${ }^{[19-28]}$ It is known that free 1,10-phenanthroline exhibits weak emission peaks at 425 and $445 \mathrm{~nm}$ in the solid state at room temperature (see Supporting Information). The enhancement and the blue shift of the luminescence of the 1,10-phenanthroline ligand compared to that of free 1,10-phenanthroline may, therefore, be attributed to the chelating effect of the 1,10-phenanthroline ligand to the $\mathrm{Zn}^{2+}$ ion. This effectively enhances the rigidity of the ligand and reduces the loss of energy by radiationless decay of the intraligand emission of the excited state. Similar blue-shifts involving rigid ligand molecules and coordination polymers have been observed before. ${ }^{[28-30]}$ In addition, fluorescent emission of carboxylate ligands resulting 


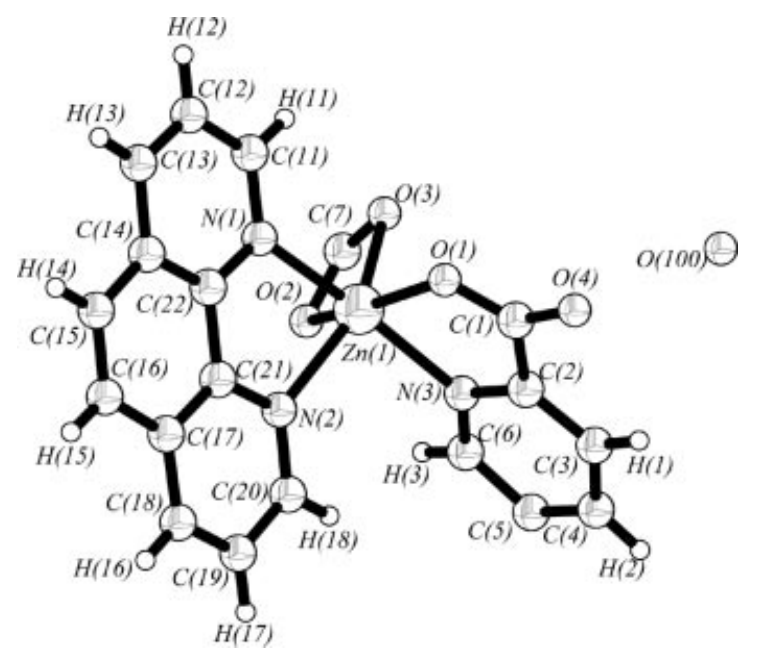

Figure 3. ORTEP drawing of ${ }_{\infty}^{1}\left[\left\{\mathrm{Zn}\left(\mathrm{C}_{12} \mathrm{H}_{8} \mathrm{~N}_{2}\right)\right\}\left\{\mathrm{C}_{5} \mathrm{H}_{3} \mathrm{~N}(\mathrm{COO})_{2}\right\} \cdot\right.$ $\left.0.5 \mathrm{H}_{2} \mathrm{O}\right](2)$ showing the asymmetric unit. Thermal ellipsoids are given at $50 \%$ probability.

Table 3. Selected bond lengths $[\AA]$ and angles $\left[^{\circ}\right]$ in ${ }_{\infty}^{1}\left[\left\{\mathrm{Zn}\left(\mathrm{C}_{12} \mathrm{H}_{8}-\right.\right.\right.$ $\left.\left.\left.\mathrm{N}_{2}\right)\right\}\left\{\mathrm{C}_{5} \mathrm{H}_{3} \mathrm{~N}(\mathrm{COO})_{2}\right\} \cdot 0.5 \mathrm{H}_{2} \mathrm{O}\right](2)$ and ${ }_{\infty}^{1}\left[\left\{\mathrm{Zn}\left(\mathrm{C}_{12} \mathrm{H}_{8} \mathrm{~N}_{2}\right)\right\}\left\{\mathrm{C}_{3} \mathrm{HN}_{2^{-}}\right.\right.$ $\left.\left.(\mathrm{COO})_{2}\right\}\right](3)$.

\begin{tabular}{lclc}
\hline & & 3 \\
\hline $\mathrm{Zn}(1)-\mathrm{O}(1)$ & $2.057(4)$ & $\mathrm{Zn}(1)-\mathrm{O}(1)$ & $2.2271(19)$ \\
$\mathrm{Zn}(1)-\mathrm{O}(2)$ & $2.312(5)$ & $\mathrm{Zn}(1)-\mathrm{O}(4)$ & $2.222(2)$ \\
$\mathrm{Zn}(1)-\mathrm{O}(3)$ & $2.118(4)$ & $\mathrm{Zn}(1)-\mathrm{N}(1)$ & $2.143(2)$ \\
$\mathrm{Zn}(1)-\mathrm{N}(1)$ & $2.151(4)$ & $\mathrm{Zn}(1)-\mathrm{N}(2)$ & $2.286(2)$ \\
$\mathrm{Zn}(1)-\mathrm{N}(2)$ & $2.163(4)$ & $\mathrm{Zn}(1)-\mathrm{N}(3)$ & $2.073(2)$ \\
$\mathrm{Zn}(1)-\mathrm{N}(3)$ & $2.121(4)$ & $\mathrm{Zn}(1)-\mathrm{N}(4)$ & $2.100(2)$ \\
$\mathrm{O}(1)-\mathrm{Zn}(1)-\mathrm{O}(3)$ & $103.08(17)$ & $\mathrm{N}(3)-\mathrm{Zn}(1)-\mathrm{N}(4)$ & $103.30(8)$ \\
$\mathrm{O}(1)-\mathrm{Zn}(1)-\mathrm{N}(3)$ & $79.07(14)$ & $\mathrm{N}(3)-\mathrm{Zn}(1)-\mathrm{N}(1)$ & $158.67(8)$ \\
$\mathrm{O}(3)-\mathrm{Zn}(1)-\mathrm{N}(3)$ & $98.19(14)$ & $\mathrm{N}(4)-\mathrm{Zn}(1)-\mathrm{N}(1)$ & $96.94(8)$ \\
$\mathrm{O}(1)-\mathrm{Zn}(1)-\mathrm{N}(1)$ & $90.69(14)$ & $\mathrm{N}(3)-\mathrm{Zn}(1)-\mathrm{O}(4)$ & $98.01(8)$ \\
$\mathrm{O}(3)-\mathrm{Zn}(1)-\mathrm{N}(1)$ & $95.17(14)$ & $\mathrm{N}(4)-\mathrm{Zn}(1)-\mathrm{O}(4)$ & $78.54(8)$ \\
$\mathrm{N}(3)-\mathrm{Zn}(1)-\mathrm{N}(1)$ & $164.70(14)$ & $\mathrm{N}(1)-\mathrm{Zn}(1)-\mathrm{O}(4)$ & $92.48(8)$ \\
$\mathrm{O}(1)-\mathrm{Zn}(1)-\mathrm{N}(2)$ & $104.39(15)$ & $\mathrm{N}(3)-\mathrm{Zn}(1)-\mathrm{O}(1)$ & $79.28(7)$ \\
$\mathrm{O}(3)-\mathrm{Zn}(1)-\mathrm{N}(2)$ & $151.60(16)$ & $\mathrm{N}(4)-\mathrm{Zn}(1)-\mathrm{O}(1)$ & $92.60(8)$ \\
$\mathrm{N}(3)-\mathrm{Zn}(1)-\mathrm{N}(2)$ & $93.93(14)$ & $\mathrm{N}(1)-\mathrm{Zn}(1)-\mathrm{O}(1)$ & $93.29(8)$ \\
$\mathrm{N}(1)-\mathrm{Zn}(1)-\mathrm{N}(2)$ & $77.50(14)$ & $\mathrm{O}(4)-\mathrm{Zn}(1)-\mathrm{O}(1)$ & $169.95(7)$ \\
$\mathrm{O}(1)-\mathrm{Zn}(1)-\mathrm{O}(2)$ & $158.01(15)$ & $\mathrm{N}(3)-\mathrm{Zn}(1)-\mathrm{N}(2)$ & $84.99(8)$ \\
$\mathrm{O}(3)-\mathrm{Zn}(1)-\mathrm{O}(2)$ & $58.98(16)$ & $\mathrm{N}(4)-\mathrm{Zn}(1)-\mathrm{N}(2)$ & $171.54(8)$ \\
$\mathrm{N}(3)-\mathrm{Zn}(1)-\mathrm{O}(2)$ & $90.45(15)$ & $\mathrm{N}(1)-\mathrm{Zn}(1)-\mathrm{N}(2)$ & $74.63(8)$ \\
$\mathrm{N}(1)-\mathrm{Zn}(1)-\mathrm{O}(2)$ & $102.86(15)$ & $\mathrm{O}(4)-\mathrm{Zn}(1)-\mathrm{N}(2)$ & $102.24(7)$ \\
$\mathrm{N}(2)-\mathrm{Zn}(1)-\mathrm{O}(2)$ & $95.50(14)$ & $\mathrm{O}(1)-\mathrm{Zn}(1)-\mathrm{N}(2)$ & $87.23(7)$ \\
\hline & & & \\
\hline
\end{tabular}

from the $\pi^{*} \rightarrow \mathrm{n}$ transition is very weak compared with that of the $\pi^{*} \rightarrow \pi$ transition of the 1,10-phenanthroline ligand. The strongly electron-withdrawing carboxylate group results in a fluorescence quenching, so the carboxylate ligands hardly contribute to the fluorescent emission of the as-synthesized polymers. As can be seen, the main emission bands of $\mathbf{2}$ and $\mathbf{3}$ are located almost at the same position, but with differences in the band shapes, which has been attributed to the $\pi^{*} \rightarrow \pi$ transition of the coordinated 1,10-phenanthroline ligand. ${ }^{[28-30]}$ The differences in the band shape might also be due to the minor differences in the structural topologies of the two structures.

The three new compounds were obtained by employing hydrothermal methods. The compounds have zero- and one-dimensional structures. While $\mathbf{1}$ forms with a zero-di-

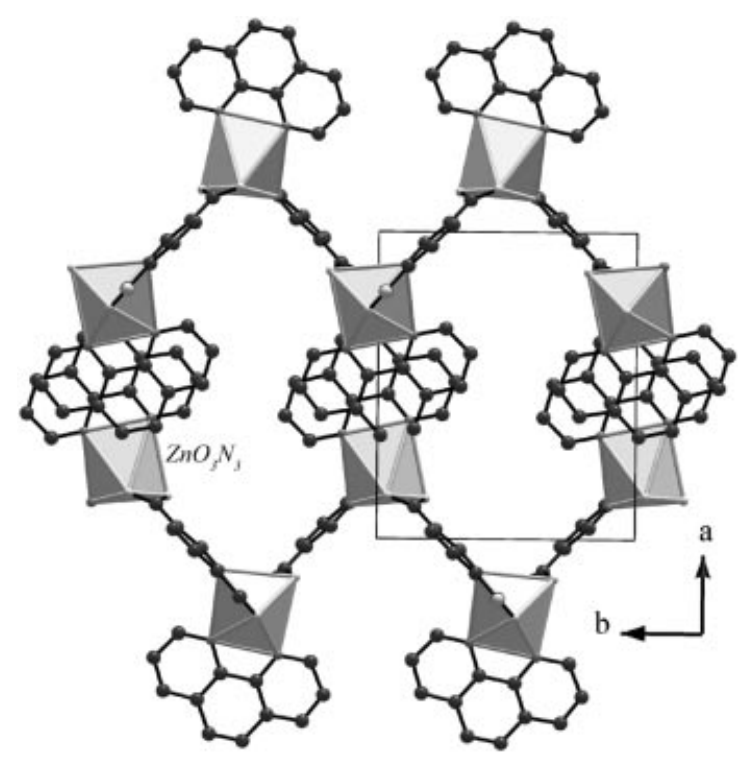

Figure 4. One-dimensional zig-zag chains observed in $\mathbf{2}$ in the $a b$ plane. Note that the 1,10-phenanthroline ligands occupy interchain spaces and interact through $\pi \cdots \pi$ interactions (see text).

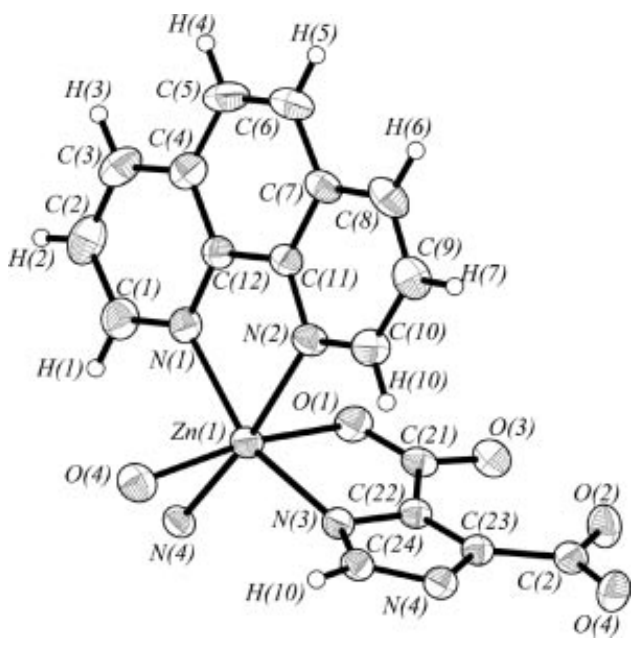

Figure 5. ORTEP drawing of ${ }_{\infty}^{1}\left[\left\{\mathrm{Zn}\left(\mathrm{C}_{12} \mathrm{H}_{8} \mathrm{~N}_{2}\right)\right\}\left\{\mathrm{C}_{3} \mathrm{HN}_{2}(\mathrm{COO})_{2}\right\}\right]$ (3) showing the asymmetric unit. Thermal ellipsoids are given at $50 \%$ probability.

mensional molecular box structure, $\mathbf{2}$ and $\mathbf{3}$ are formed with zig-zag one-dimensional chain structures. However, all three compounds are related in a subtle way. While compound $\mathbf{2}$ is formed by adding 1,10-phenanthroline to the synthesis mixture of $\mathbf{1}, \mathbf{3}$ is obtained by replacing pyridine-2,5-dicarboxylic acid with imidazole-4,5-dicarboxylic acid in the synthesis mixture of $\mathbf{2}$. The secondary ligand, 1,10-phenanthroline, replaces the terminal water molecules in $\mathbf{1}$ and, during this process, the coordination environment of the $\mathrm{Zn}^{2+}$ ions also changes from distorted square-pyramidal (five-coordinate) to an octahedral one (six-coordinate). In addition, the coordination mode of the pyridine-2,5-dicarboxylate also changes from being a simple monodentate coordination in $\mathbf{1}$ to a combination of mono- and bis(didentate) in 2. In 3, however, the imidazole-4,5-dicarboxylate has 


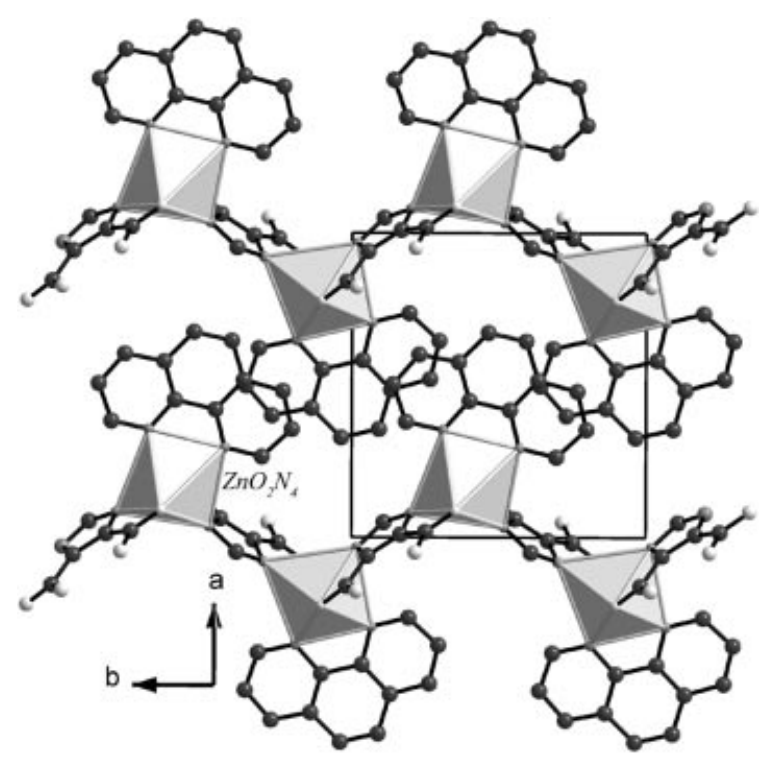

Figure 6. One-dimensional chains observed in $\mathbf{3}$ in the $a b$ plane. Note that the 1,10-phenanthroline ligands occupy the inter-chain spaces and interact through $\pi \cdots \pi$ interactions (see text).

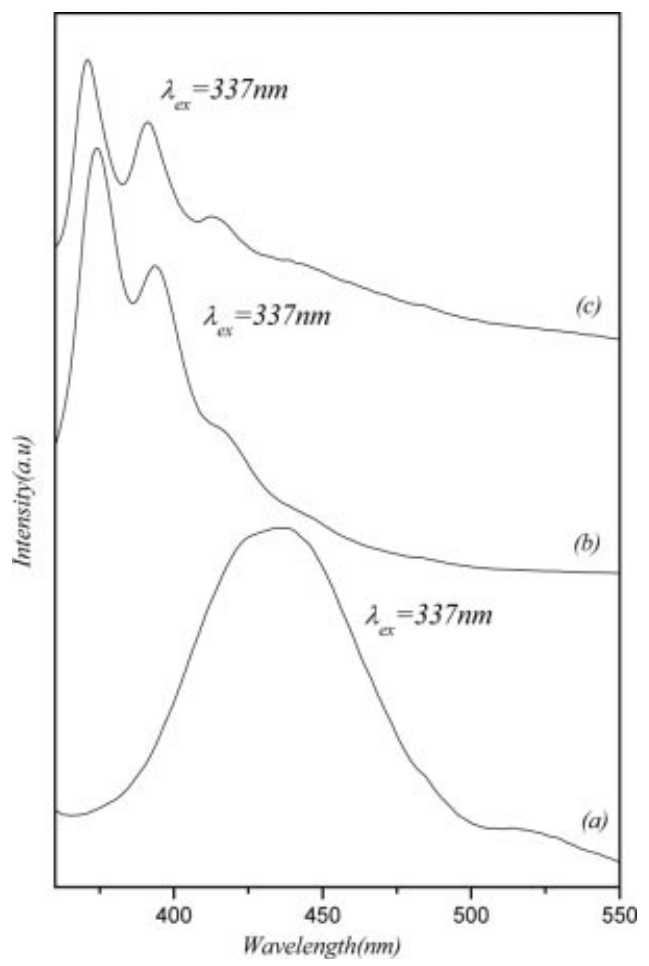

Figure 7. Emission spectra in the solid state at room temperature for (a) 1, (b) 2, and (c) 3 .

a simple monodentate connectivity with $\mathrm{Zn}^{2+}$ ions. The striking similarities between $\mathbf{2}$ and $\mathbf{3}$ can best be seen when viewing the structures down the chain axis. The 1,10-phenanthroline ligands occupy similar positions in both 2 and 3 , thus indicating that the favorable $\pi \cdots \pi$ interactions between the ligand molecules play an important role in the formation and stability of these compounds.
The use of heterocyclic carboxylic acids provides both the proton donor as well as the acceptor through the carboxylate oxygen and the ring nitrogen atoms. Both these centers are highly accessible to the participating metal ions during the synthesis for the formation of both monodentate and/or multidentate $\mathrm{M}-\mathrm{O}$ and $\mathrm{M}-\mathrm{N}$ bonds. The structural motifs thus formed can then readily participate in hydrogen bonding to give rise to a variety of networks. In the present system of compounds, we observe differences in the connectivity of the carboxylate oxygen atoms but the nitrogen atom, in all cases, participates in bonding with the $\mathrm{Zn}^{2+}$ ions. Similar behavior has been observed before. ${ }^{[17]}$ In addition, moderate $\mathrm{O}-\mathrm{H} \cdot \cdots \mathrm{O}$-type hydrogen bonding is observed in $\mathbf{1}$ that gives rise to extended networks. It is likely that the presence of the rather bulky 1,10-phenanthroline as the secondary ligand in $\mathbf{2}$ and $\mathbf{3}$ prevents the formation of any hydrogen-bond interactions and only $\pi \cdots \pi$ interactions are observed (Figure 8).

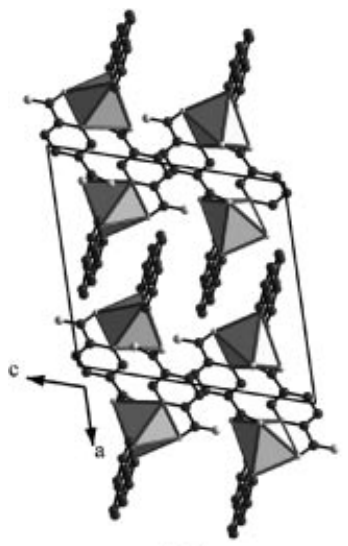

(a)

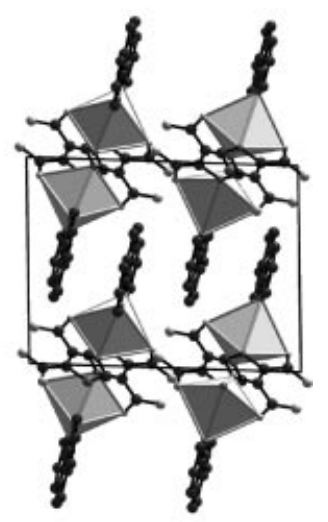

(b)
Figure 8. Arrangement of the one-dimensional chains in the $a c$ plane for (a) 2 and (b) 3. Note the similarity between the two structures and the arrangement of the 1,10-phenanthroline ligands.

The role of $\pi \cdots \pi$ interactions in the stability of lower dimensional structures in metal-organic coordination polymers has been a topic of much interest. ${ }^{[31,32]}$ In the present compounds $\pi \cdots \pi$ interactions involving the 1,10-phenanthroline ligands are observed, especially in $\mathbf{2}$ and $\mathbf{3}$. The centroid-centroid distance $(d)$ between the 1,10-phenanthroline rings and their interplanar angles $(\theta)$ for $\mathbf{2}$ and $\mathbf{3}$ are shown in Figure 9. Favorable $\pi \cdots \pi$ interactions between these rings, with $d=3.66 \AA$ and $3.45 \AA$ and $\theta=0.8^{\circ}$ and $1.93^{\circ}$ for $\mathbf{2}$ and $\mathbf{3}$, respectively, are observed. From the interplanar angles $(\theta)$, it is clear that the two 1,10-phenanthroline rings are arranged one over the other, but are stacked anti-parallel to each other. This type of anti-parallel arrangement of aromatic rings is commonly observed in systems exhibiting dipolar properties. To understand the role of $\pi \cdots \pi$ interactions, we have performed preliminary calculations using the AM1-parameterized Hamiltonian available in the Gaussian program suite. ${ }^{[33,34]}$ AM1 methods, together with a semi-classical dipolar description, have been employed recently to establish the relationship between the stability and geometries of organic molecules. ${ }^{[35]}$ 
From these calculations, the dipole moment of the independent single 1,10-phenanthroline molecules was found to be 2.8 Debye; in $\mathbf{2}$ and $\mathbf{3}$, the dipole moment values for the stacked arrangement were found to be exactly zero. It is likely that the anti-parallel arrangement of the 1,10-phenanthroline molecules reduces the dipole-dipole repulsion and paves the way for $\pi$-electron polarizations.

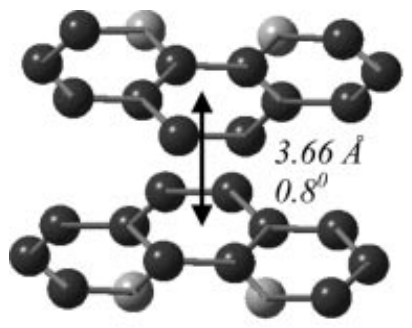

(a)

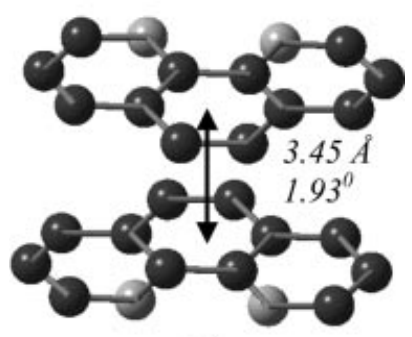

(b)

Figure 9. Stacking of the 1,10-phenanthrolines in 2 and 3. Note that in both the cases the molecules are in an anti-parallel arrangement.

We also evaluated the strength of the $\pi \cdots \pi$ interactions in $\mathbf{2}$ and $\mathbf{3}$ based on single-point energy calculations, without symmetry constraints, on the basis of the crystal structure geometry. The $\pi \cdots \pi$ interaction energies were found to be 7.27 and $7.32 \mathrm{kcalmol}^{-1}$, respectively, for 2 and 3 . These energies are comparable to the intermediate hydrogen-bond strengths (approx. $10-15 \mathrm{kcalmol}^{-1}$ ) in $\mathrm{N}-\mathrm{H} \cdots \mathrm{O}$ and $\mathrm{O}-$ $\mathrm{H} \cdots \mathrm{O}$ hydrogen-bond systems. ${ }^{[36]}$ It should be noted that the carboxylate groups in $\mathbf{1}$ are stacked exactly one over other, while in $\mathbf{2}$ and $\mathbf{3}$ they are in an anti-parallel arrangement (Figure 10). It is likely that the presence of 1,10-phenanthroline ligands and their $\pi \cdots \pi$ interactions influence the geometry of the carboxylate groups in $\mathbf{2}$ and $\mathbf{3}$, although all the carboxylate groups are separated by $6-7 \AA$ in the structures. When the separation between the benzene rings is greater, as for instance between the pyridinecarboxylates in $\mathbf{1}$ and $\mathbf{2}$ and between the imidazolecarboxylates in $\mathbf{3}$, the $\pi \cdots \pi$ interactions are negligible. Of the three compounds described in this paper, the moderate hydrogen-bond interaction energy in $\mathbf{1}$ and the $\pi \cdots \pi$ interactions in $\mathbf{2}$ and $\mathbf{3}$ appear to play an important role for the observed structural stability. It is likely that the study of similar systems would open up new avenues for our understanding of the nature of $\pi \cdots \pi$ interactions and their role in structural stability.

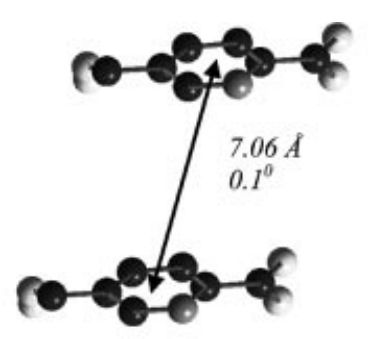

(a)

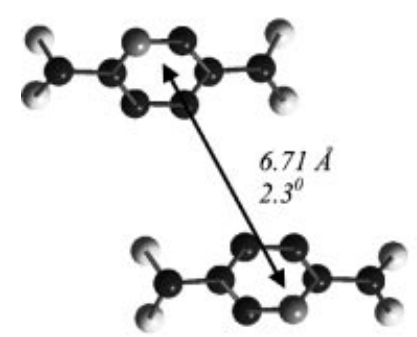

(b)

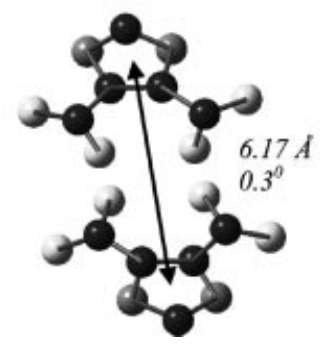

(c)

Figure 10. Arrangement of the carboxylate units in (a) 1, (b) 2, and (c) 3 .

\section{Experimental Section}

General: All three compounds were synthesized by hydrothermal methods. In a typical synthesis of $1, \mathrm{ZnSO}_{4} \cdot 7 \mathrm{H}_{2} \mathrm{O}(0.144 \mathrm{~g}$, $0.5 \mathrm{mmol}$ ) was dissolved in $4 \mathrm{~mL}$ of $0.125 \mathrm{M} \mathrm{NaOH}$ solution. Pyridine-2,5-dicarboxylic acid $\left(\mathrm{H}_{2} \mathrm{PyDC} ; 0.085 \mathrm{~g}, 0.5 \mathrm{mmol}\right)$ and $0.03 \mathrm{~mL}$ of triethylamine $\left(\mathrm{Et}_{3} \mathrm{~N}\right)$ were then added, with continuous stirring, and the mixture was homogenized at room temperature for $30 \mathrm{~min}$. The final mixture was sealed in a 7-mL PTFE-lined stainless-steel acid digestion bomb and heated at $150{ }^{\circ} \mathrm{C}$ for $5 \mathrm{~d}$. The initial and final $\mathrm{pH}$ of the reaction mixture were 4 and 3.5, respectively. The final product contained large quantities of colorless rectangular crystals, which were filtered off, washed with copious quantities of deionized water under vacuum, and dried under ambient conditions. Compound $\mathbf{2}$ was prepared under identical synthetic conditions but with the addition of $0.1 \mathrm{~g}$ of 1,10 -phenanthroline to the reaction mixture. For 3, zinc acetate $(0.056 \mathrm{~g}$, $0.25 \mathrm{mmol}$ ) was dissolved in $10 \mathrm{~mL}$ of water along with imidazole4,5-dicarboxylic acid $(0.085 \mathrm{~g}, 0.5 \mathrm{mmol}), \mathrm{NaOH}(0.04 \mathrm{~g}, 1 \mathrm{mmol})$, $\mathrm{Et}_{3} \mathrm{~N}(0.03 \mathrm{~mL}, 0.25 \mathrm{mmol})$, and 1,10 -phenanthroline $(0.05 \mathrm{~g}$, $0.25 \mathrm{mmol}$ ). The reaction mixture was heated in a $23-\mathrm{mL}$ autoclave at $150{ }^{\circ} \mathrm{C}$ for $7 \mathrm{~d}$. The initial and final $\mathrm{pH}$ of the reaction mixture were 10 and 6 , respectively. The colorless crystals obtained were filtered, washed with water, and dried under ambient conditions. 1: $\mathrm{C}_{14} \mathrm{H}_{14} \mathrm{~N}_{2} \mathrm{O}_{12} \mathrm{Zn}_{2}$ (533.01): calcd. C 31.52, H 2.66, N 5.25; found C 31.4, H 2.53, N 5.1. 2: $\mathrm{C}_{19} \mathrm{H}_{12} \mathrm{~N}_{3} \mathrm{O}_{4.5} \mathrm{Zn}$ (419.68): calcd. C 54.33, $\mathrm{H}$ 2.85, N 10.01; found C 54.4, H 2.79, N 10.14. 3: $\mathrm{C}_{17} \mathrm{H}_{9} \mathrm{~N}_{4} \mathrm{O}_{4} \mathrm{Zn}$ (398.65): calcd. C 51.17, H 2.26, N 14.05; found C 51.27, H 2.33, N 13.96. The powder XRD patterns were recorded on crushed single crystals in the $2 \theta$ range $5-50^{\circ}$ using $\mathrm{Cu}-K_{\alpha}$ radiation (Rich-Seifert, 3000TT). The XRD patterns indicated that the products were new materials; the patterns were entirely consistent with the structures 
Table 4. Crystal data and structure-refinement parameters for ${ }_{\infty}^{0}\left[\left\{\mathrm{Zn}_{2}\left(\mathrm{H}_{2} \mathrm{O}\right)_{4}\right\}\left\{\mathrm{C}_{5} \mathrm{H}_{3} \mathrm{~N}(\mathrm{COO})_{2}\right\}_{2}\right] \quad(\mathbf{1}),{ }_{\infty}^{1}\left[\left\{\mathrm{Zn}\left(\mathrm{C}_{12} \mathrm{H}_{8} \mathrm{~N}_{2}\right)\right\}\left\{\mathrm{C}_{5} \mathrm{H}_{3} \mathrm{~N}-\right.\right.$ $\left.\left.(\mathrm{COO})_{2}\right\} \cdot 0.5 \mathrm{H}_{2} \mathrm{O}\right](2)$, and ${ }_{\infty}^{1}\left[\left\{\mathrm{Zn}\left(\mathrm{C}_{12} \mathrm{H}_{8} \mathrm{~N}_{2}\right)\right\}\left\{\mathrm{C}_{3} \mathrm{HN}_{2}(\mathrm{COO})_{2}\right\}\right](3)$.

\begin{tabular}{|c|c|c|c|}
\hline Structure parameter & 1 & 2 & 3 \\
\hline Empirical formula & $\mathrm{C}_{14} \mathrm{H}_{14} \mathrm{~N}_{2} \mathrm{O}_{12} \mathrm{Zn}_{2}$ & $\mathrm{C}_{19} \mathrm{H}_{12} \mathrm{~N}_{3} \mathrm{O}_{4.5} \mathrm{Zn}$ & $\mathrm{C}_{17} \mathrm{H}_{9} \mathrm{~N}_{4} \mathrm{O}_{4} \mathrm{Zn}$ \\
\hline Formula mass & 533.01 & 419.68 & 398.65 \\
\hline Crystal system & triclinic & monoclinic & monoclinic \\
\hline Space group & $P \overline{1}$ (no. 2$)$ & $P 2_{1} / c$ (no. 14$)$ & $P 2_{1} / c($ no. 14$)$ \\
\hline$a[\AA]$ & $7.0649(2)$ & $12.6890(8)$ & $10.4517(8)$ \\
\hline$b[\AA]$ & $7.3913(2)$ & $10.2007(6)$ & $10.1014(7)$ \\
\hline$c[\AA]$ & $18.477(4)$ & $13.6742(8)$ & $13.7713(10)$ \\
\hline$a\left[^{\circ}\right]$ & $90.02(2)$ & 90 & 90 \\
\hline$\beta\left[^{\circ}\right]$ & $96.99(2)$ & $107.014(1)$ & $92.723(1)$ \\
\hline$\gamma\left[^{\circ}\right]$ & $115.68(3)$ & 90 & 90 \\
\hline Volume $\left[\AA^{3}\right]$ & $861.5(3)$ & $1692.48(18)$ & $1452.29(18)$ \\
\hline$Z$ & 2 & 4 & 4 \\
\hline$T[\mathrm{~K}]$ & $293(2)$ & 293(2) & $293(2)$ \\
\hline$\rho_{\text {calcd. }}\left(\mathrm{g} \mathrm{cm}^{-3}\right)$ & 2.055 & 1.643 & 1.823 \\
\hline$\mu\left[\mathrm{mm}^{-1}\right]$ & 2.860 & 1.487 & 1.727 \\
\hline$\theta$ range $\left[{ }^{\circ}\right]$ & $1.11-23.29$ & $1.68-23.25$ & $1.95-23.28$ \\
\hline$\lambda\left(\mathrm{Mo}-K_{\alpha}\right)[\AA]$ & 0.71073 & 0.71073 & 0.71073 \\
\hline$R$ indexes $[I>2 \sigma(I)]^{[\mathrm{a}]}$ & $R_{1}=0.0492, w R_{2}=0.1294$ & $R_{1}=0.0425, w R_{2}=0.1372$ & $R_{1}=0.0271, w R_{2}=0.0709$ \\
\hline$R$ (all data) $^{[\mathrm{a}]}$ & $R_{1}=0.0674, w R_{2}=0.1521$ & $R_{1}=0.0520, w R_{2}=0.1428$ & $R_{1}=0.0332, w R_{2}=0.0740$ \\
\hline
\end{tabular}

[a] $R_{1}=\Sigma|| F_{\mathrm{o}}|-| F_{\mathrm{c}} \| / \Sigma\left|F_{\mathrm{o}}\right| ; w R_{2}=\left\{\Sigma\left[w\left(F_{\mathrm{o}}{ }^{2}-F_{\mathrm{c}}{ }^{2}\right)^{2}\right] / \Sigma\left[w\left(F_{\mathrm{o}}{ }^{2}\right)^{2}\right\}\right]^{1 / 2} \cdot w=1 /\left[\sigma^{2}\left(F_{\mathrm{o}}\right)^{2}+(a P)^{2}+b P\right]$, where $P=\left[\max .\left(F_{\mathrm{o}}{ }^{2}, 0\right)+2\left(F_{\mathrm{c}}\right)^{2}\right] / 3$ and $a$ $=0.0460$ and $b=1.5472$ for $\mathbf{1}, a=0.0460$ and $b=1.5472$ for 2 , and $a=0.0460$ and $b=1.5472$ for 3 .

determined by single-crystal X-ray diffraction. Thermogravimetric analysis (TGA) was carried out (Metler-Toledo) under oxygen (flow rate $=50 \mathrm{~mL} \mathrm{~min}^{-1}$ ) in the temperature range $25-700^{\circ} \mathrm{C}$ (heating rate $=5^{\circ} \mathrm{Cmin}^{-1}$ ). The studies showed similar results for the compounds, with one weight loss. The total observed weight losses of 73,79 , and $78.5 \%$ for $\mathbf{1}, \mathbf{2}$, and $\mathbf{3}$, respectively, correspond well with the loss of the carboxylate and bonded water in $\mathbf{1}$ (calcd. $70 \%$ ), carboxylate, lattice water, and 1,10-phenanthroline in $\mathbf{2}$ (calcd. 79.5\%), and carboxylate and 1,10-phenanthroline in $\mathbf{3}$ (calcd. $80 \%$ ). The final calcined product was found to be crystalline by powder XRD and corresponded to ZnO (JCPDS: 36-1451). IR spectroscopic studies were carried out in the mid-IR region on $\mathrm{KBr}$ pellets (Bruker IFS-66v). The spectra show characteristic sharp lines with almost similar bands. Minor variations between the bands were found between the compounds. 1: $\tilde{v}=3467(\mathrm{~m})$ $\left(v_{\mathrm{as}} \mathrm{OH}\right), 2889(\mathrm{w})\left[\mathrm{v}_{\mathrm{s}}(\mathrm{C}-\mathrm{H})_{\text {aromatic }}\right], 1633(\mathrm{~m})\left[\mathrm{v}_{\mathrm{s}}(\mathrm{C}=\mathrm{O})\right], 1605(\mathrm{w})$ $\left(\delta_{\mathrm{s}} \mathrm{H}_{2} \mathrm{O}\right), 1575(\mathrm{~m})(\mathrm{C}-\mathrm{C})_{\text {skeletal }}, 1362(\mathrm{~s})\left[\delta_{\mathrm{s}}(\mathrm{COO})\right], 1041(\mathrm{~s})[\delta(\mathrm{C}-$ $\left.\left.\mathrm{N}_{\text {skeletal }}\right)\right], 803$ (s) $\left[\delta\left(\mathrm{CH}_{\text {aromatic }}\right)_{\text {out-of-plane }} \mathrm{cm}^{-1} \cdot \mathbf{2}: \tilde{\mathrm{v}}=3475(\mathrm{~m})\right.$ $\left(v_{\mathrm{as}} \mathrm{OH}\right), 1645(\mathrm{~s})\left[\mathrm{v}_{\mathrm{s}}(\mathrm{C}=\mathrm{O})\right], 1605(\mathrm{w})\left(\delta_{\mathrm{s}} \mathrm{H}_{2} \mathrm{O}\right), 1351(\mathrm{~s})\left[\delta_{\mathrm{s}}(\mathrm{COO})\right]$, $1294(\mathrm{~m})\left[\delta\left(\mathrm{CH}_{\text {aromatic }}\right)_{\text {in-of-plane }}\right], 1036(\mathrm{~s})\left[\delta\left(\mathrm{C}-\mathrm{N}_{\text {skeletal }}\right)\right], 848(\mathrm{~s})$ $\left[\delta\left(\mathrm{CH}_{\text {aromatic }}\right)_{\text {out-of-plane }}\right] \mathrm{cm}^{-1} .3: \tilde{v}=2888(\mathrm{w})\left[\mathrm{v}_{\mathrm{s}}(\mathrm{C}-\mathrm{H})_{\text {aromatic }}\right]$, $1567(\mathrm{~s})\left[v_{\mathrm{s}}(\mathrm{C}=\mathrm{O})\right], 1552(\mathrm{~s})\left[(\mathrm{C}-\mathrm{C})_{\text {skeletal }}\right], 1392(\mathrm{~s})\left[\delta_{\mathrm{s}}(\mathrm{COO})\right], 1299$ (s) $\left[\delta\left(\mathrm{CH}_{\text {aromatic }}\right)_{\text {in-of-plane }}\right], 1034(\mathrm{w})\left[\delta\left(\mathrm{C}-\mathrm{N}_{\text {skeletal }}\right)\right], 910(\mathrm{~s})[\delta-$ $\left.\left(\mathrm{CH}_{\text {aromatic }}\right)_{\text {out-of-plane }}\right] \mathrm{cm}^{-1}$. A suitable single crystal of each compound was carefully selected under a polarizing microscope and glued to a thin glass fiber. Crystal structure determination by Xray diffraction was performed with a Siemens Smart-CCD diffractometer equipped with a normal focus, $2.4 \mathrm{~kW}$ sealed-tube $\mathrm{X}$ ray source (Mo- $K_{\alpha}$ radiation, $\lambda=0.71073 \AA$ ) operating at $40 \mathrm{kV}$ and $40 \mathrm{~mA}$. An empirical absorption correction was applied using the SADABS program. ${ }^{[37]}$ The structure was solved and refined with the SHELXTL-PLUS suite of programs. ${ }^{[38]}$ All the hydrogen atoms of the carboxylic acids and the bound water molecules were located in the difference Fourier maps. For the final refinement, the hydrogen atoms on the carboxylic acid were placed geometrically and held in the riding mode. Final refinement included atomic positions for all the atoms, anisotropic thermal parameters for all the non-hydrogen atoms, and isotropic thermal parameters for all the hydrogen atoms. Full-matrix least-squares refinement against
$\left|F^{2}\right|$ was carried out with the SHELXTL-PLUS ${ }^{[38]}$ suite of programs. Details of the structure solution and final refinement for all three compounds are given in Table 4. CCDC-258001 to -258003 (1-3) contain the supplementary crystallographic data for this paper. These data can be obtained free of charge from The Cambridge Crystallographic Data Centre via www.ccdc.cam.ac.uk/data_request/cif.

Supporting Information (see footnote on the first page of this article): Experimental and simulated powder XRD patterns, IR and TGA curves.

\section{Acknowledgments}

S. N. thanks the Department of Science and Technology (DST), Government of India, for the award of a research grant, and P. M. thanks the Council of Scientific and Industrial Research (CSIR), Government of India, for the award of a research fellowship.

[1] C. N. R. Rao, S. Natarajan, R. Vaidhyanathan, Angew. Chem. 2004, 116, 1490-1521; Angew. Chem. Int. Ed. 2004, 43, 14661496.

[2] B. Chen, M. Eddaoudi, T. M. Reineke, J. W. Kampf, M. O'Keeffe, O. M. Yaghi, J. Am. Chem. Soc. 2000, 122, 11 55911560.

[3] K. Barthelet, J. Marrot, D. Riou, G. Ferey, Angew. Chem. Int. Ed. 2002, 41, 281-284.

[4] C. J. Kepert, T. J. Prior, M. J. Rosseinsky, J. Am. Chem. Soc. 2000, 122, 5158-5168.

[5] J. C. Dai, X. T. Wu, Z. Y. Fu, C. P. Cui, S. H. Hu, W. X. Du, L. M. Wu, H. H. Zhang, R. Q. Sun, Inorg. Chem. 2002, 41, $1391-1396$.

[6] M. Edgar, R. Mitchell, A. M. Z. Slawin, P. Lightfoot, P. A. Wright, Chem. Eur. J. 2001, 7, 5168-5175.

[7] W. Chen, J. Y. Wang, C. Chen, Q. Yue, H. M. Yuan, J. S. Chen, S. N. Wang, Inorg. Chem. 2003, 42, 944-948.

[8] R. Murugavel, D. Krishnamurthy, M. Sathiyendiran, J. Chem. Soc., Dalton Trans. 2002, 34-39.

[9] M. Sanselme, J. M. Greneche, M. R. Cavellec, G. Feréy, Chem. Commun. 2002, 2172-2173. 
[10] R. Cao, Q. Shi, D. Sun, M. Hong, W. Bi, Y. Zhao, Inorg. Chem. 2002, 41, 6161-6168.

[11] W. Lin, O. R. Evans, R. G. Xiong, Z. Wang, J. Am. Chem. Soc. 1998, 120, 13 272-13 273.

[12] O. R. Evans, R. G. Xiong, Z. Wang, G. K. Wong, W. Lin, Angew. Chem. 1999, 111, 557-559; Angew. Chem. Int. Ed. 1999, $38,536-538$.

[13] W. Lin, L. Ma, O. R. Evans, Chem. Commun. 2000, 2263-2264.

[14] P. Ayyappan, O. R. Evans, W. Lin, Inorg. Chem. 2001, 40, 4627-2632.

[15] L. Pan, X. Y. Huang, J. Li, Y. G. Wu, N. W. Zheng, Angew. Chem. 2000, 112, 537-540; Angew. Chem. Int. Ed. 2000, 39, $527-530$

[16] L. Pan, N. Ching, X. Y. Huang, J. Li, Inorg. Chem. 2001, 40, 1271-1283.

[17] L. Pan, N. Ching, X. Y. Huang, J. Li, Chem. Eur. J. 2001, 7, 4431-4437.

[18] A. Thirumurugan, S. Natarajan, Dalton Trans. 2004, 2923 2928.

[19] A. Thirumurugan, S. Natarajan, Solid State Sci. 2004, 6, 599 604.

[20] J. Tao, J. X. Shi, M. L. Tong, X. X. Zhang, X. M. Chen, Inorg. Chem. 2001, 40, 6328-6330.

[21] Y. Hou, S. Wang, E. Shen, E. Wang, D. Xiao, Y. Li, L. Xu, C. $\mathrm{Hu}$, Inorg. Chim. Acta 2004, 357, 3155-3161.

[22] Y. B. Chen, J. Zhang, J. K. Cheng, Y. Kang, Z. J. Li, Y. G. Yao, Inorg. Chem. Commun. 2004, 7, 1139-1141.

[23] G. P. Yong, Z. Y. Wang, Y. Cui, Eur. J. Inorg. Chem. 2004, $4317-4323$.

[24] J. F. Ma, J. Yang, S. L. Li, S. Y. Song, Cryst. Growth Des. 2005, $5,807-812$

[25] X. Shi, G. S. Zhu, Q. R. Fang, G. Wu, G. Tian, R. W. Wang, D. L. Zhang, M. Xue, S. L. Qiu, Eur. J. Inorg. Chem. 2004, 185-191.

[26] J. C. Dai, X. T. Wu, Z. Y. Fu, S. M. Hu, W. X. Du, C. P. Cui, Chem. Commun. 2002, 12-13.

[27] X. M. Quyang, D. J. Liu, T. Okamura, H. W. Bu, W. Y. Sun, W. X. Tang, N. Ueyama, Dalton Trans. 2003, 1836-1845.

[28] X. Shi, G. Zhu, X. Wang, G. Li, Q. Gand, X. Zhao, G. Wu, G. Tian, M. Xue, R. Wang, S. Qiu, Cryst. Growth Des. 2004, 5, 341-346.
[29] L. Y. Zhang, G. F. Liu, S. L. Zheng, B. H. Ye, X. M. Zhang, X. M. Chen, Eur. J. Inorg. Chem. 2003, 2965-2971 and references cited therein.

[30] X. M. Zhang, M. L Tong, M. L. Gong, X. M. Chen, Eur. J. Inorg. Chem. 2003, 138-142.

[31] C. A. Hunter, J. K. M. Sanders, J. Am. Chem. Soc. 1990, 112, $5525-5534$.

[32] C. A. Hunter, J. Singh, J. K. M. Sanders, J. Mol. Biol. 1991, 218, 837-846.

[33] M. J. Frisch, G. W. Trucks, H. B. Schlegel, G. E. Scuseria, M. A. Robb, J. R. Cheeseman, J. A. Montgomery, Jr., T. Vreven, K. N. Kudin, J. C. Burant, J. M. Millam, S. S. Iyengar, J. Tomasi, V. Barone, B. Mennucci, M. Cossi, G. Scalmani, N. Rega, G. A. Petersson, H. Nakatsuji, M. Hada, M. Ehara, K. Toyota, R. Fukuda, J. Hasegawa, M. Ishida, T. Nakajima, Y. Honda, O. Kitao, H. Nakai, M. Klene, X. Li, J. E. Knox, H. P. Hratchian, J. B. Cross, C. Adamo, J. Jaramillo, R. Gomperts, R. E. Stratmann, O. Yazyev, A. J. Austin, R. Cammi, C. Pomelli, J. W. Ochterski, P. Y. Ayala, K. Morokuma, G. A. Voth, P. Salvador, J. J. Dannenberg, V. G. Zakrzewski, S. Dapprich, A. D. Daniels, M. C. Strain, O. Farkas, D. K. Malick, A. D. Rabuck, K. Raghavachari, J. B. Foresman, J. V. Ortiz, Q. Cui, A. G. Baboul, S. Clifford, J. Cioslowski, B. B. Stefanov, G. Liu, A. Liashenko, P. Piskorz, I. Komaromi, R. L. Martin, D. J. Fox, T. Keith, M. A. Al-Laham, C. Y. Peng, A. Nanayakkara, M. Challacombe, P. M. W. Gill, B. Johnson, W. Chen, M. W. Wong, C. Gonzalez, J. A. Pople, Gaussian 03, Revision B.05, Gaussian, Inc., Pittsburgh, PA, USA, 2003.

[34] M. J. S. Dewar, E. G. Zoebisch, E. F. Healy, J. J. P. Stewart, J. Am. Chem. Soc. 1985, 107, 3902-3909.

[35] A. Dutta, S. K. Pati, J. Chem. Phys. 2003, 118, 8420-8427.

[36] Hydrogen Bonding: A Theoretical Perspective (Ed.: S. Scheiner), Oxford University Press, 1997.

[37] G. M. Sheldrick, SADABS, Siemens Area Detector Absorption Correction Program, University of Göttingen, Göttingen, Germany, 1994.

[38] G. M. Sheldrick, SHELXTL-PLUS, Program for Crystal Structure Solution and Refinement, University of Göttingen, Göttingen, Germany, 1997.

Received: November 8, 2004, 